\title{
Cyber felony in India
}

\author{
Dr.Gadekar Vithal Laxman (Assistant Professor) \\ IBMRD, Ahmednagar (MS)
}

\begin{abstract}
Cyber felony can be defined as an "illegal act in which a computer is a tool or a goal or both". Late, the use of computers has become extremely coarse and amateur. With the intention of regulating felony activities in the cyber world and protecting the technological advancement system, the Indian parliament approved the law on IT Act, 2000. It was the first global law of India to deal with machinery in the field of e-commerce, egovernance, electronic banking services, as well as penalties and punishments regarding computer felonies. This document will discuss the common types of cyber felony and measures to prevent cyber felony.
\end{abstract}

KEYWORDS: Cyber bullying, cyberspace, phishing, spam.

\section{INTRODUCTION:}

Computer felony's include criminal activities carried out using computers that further perpetrate felony's such as phishing, counterfeiting, cyber-bullying, pornography, bombardment of e-mails, spam, sale of illegal articles, etc. Although cyber-felony has its general meaning as "A legal error that can be followed by criminal proceedings that can result in punishment".

Cyber Security is defined as a felony in which a computer is subject to felony (piracy, phishing, spam) or used as a tool to commit a felony (child pornography, hate felonies). Cyber-criminals can use computer machinery to access personal information, trade secrets or use the Internet for venomous or misuse purposes.

Cyber security laws helps in preventing or reducing large-scale damage to cyber-felony activities and protects access to information, privacy, communications, intellectual property (IP) and freedom of expression in relation to the use of the Internet, websites, and email, computers, mobile phones, software and hardware, such as data accumulator. Since cyber laws vary according to jurisdiction and country, the application is a challenge and the redress goes from fines to imprisonment. 


\section{LITERATURE REVIEW:}

\subsection{Animesh Sarmahand and Amlan Jyoti Baruah :}

The authors of this article claim that criminal activities or Internet related offenses / felonies are called cyber felony. To prohibit cyber criminals, the term "Cyber Law" has been introduced. It covers a big area, covering many secondary topics, as well as freedom of expression, Internet access and use and online security or online privacy. The primary goal of the author when writing this document was to spread the content of cyber felony among ordinary people. At the end of the document "A Brief Study on Cyber Felony and Cyber Laws in India", the authors said that cyber felony can never be recognized.

\subsection{Anuraj Singh:}

Cyber law in India needs such laws so that people can make online buying transactions via credit cards without fear of abuse. Cyber felony is inevitable, omnipresent and increasingly linked to different parts and areas of criminal contexts. This rise and this network have given rise to cyberspace which controls and manages to provide equal opportunities and facilities for all people to access any type of information. Due to the gradual growth of the Internet, machinery abuse is gradually expanding, leading to cyber felony. Cyber felony is basically an illegal act that leads to criminal activity. This document illustrates and focuses on cyber felony, its impact on society, the types of threats and cyber security. Today, cyber felony problems and theft have become tremendously evident, particularly those related to copyright infringement, piracy, child pornography, and childcare and identity theft.

\section{OBJECTIVE:}

To. Understand the concept of cyber-felony.

To get an overview of the common types of cyber-felony.

Know the steps to prevent cyber felony. 


\subsection{CYBER FELONY AND CYBER LAW:}

Cyber felony is the result of our high dependence on cyberspace or the so-called Internet world. Computer felony's are illegal / illegal acts in which the computer is used as a tool or a target or both. The first reported computer felony was in the 1820s. The enormous growth of e-commerce (e-commerce) and the exchange of online shares led to a phenomenal outbreak in cyber felony incidents. The IT Act, 2000, is the main legislation dealing with the rules and regulations relating to the cyber world; it provides a step forward in the field of law with the changing and modernized dimension of the felony world. The main purpose of the law is to provide legal authentication for electronic commerce and to facilitate the submission of electronic registers to the government. The computer law also criminalizes various computer felonies and establishes severe penalties (prison sentences of up to 10 years and compensation up to one lac rupees.

\subsection{COMMON CYBER FELONYS:}

The different types of computer felony's are:

$\square$ Unauthorized access and piracy:

$\square$ Pornography:

$\square$ Hijacking the Web:

Cyber bullying:

$\square$ Child pornography:

$\square$ Virus attacks:

$\square$ Denial of Service attack:

$\square$ Salami attacks:

Software piracy:

Phishing:

$\square$ Sale of illegal items:

Online game:

Cyber Defamation:

$\square$ Email spoofing:

$\square$ Falsification:

$\square$ Theft of information in electronic format:

Bombardment by email: 
Data distribution:

Theft of time on the Internet:

$\square$ Theft of the computer system:

Physical damage to a computer system:

Violation of privacy and confidentiality:

Data distribution:

Investment fraud:

Cyber terrorism:

\subsection{STATISTICS ON CYBER FELONY:}

India has seen a 45\% increase in cyber felony incidents under the IT Act, 2000 from 2011 to 2016, according to a recent joint study by ASSOCHAM-NEC.

Symantec Corp ranked India among the top five cyber felony countries, revising 2012-17, the number of Internet users grew at a compound annual rate of $44 \%$, of which India ranked third after the United States and China. The use of the latest technologies such as artificial intelligence, big data analysis, facial recognition, IoT, etc., to identify and capture suspects / criminals, has gained a lot of awareness among different law enforcement agencies. However, the implementation of these technologies is not at the national level but at the state level, which makes it crucial for the central government to fund and support state-level law enforcement agencies to use technologies to upgrade their surveillance methods, has said the study.

The Indian government and several law enforcement agencies have taken the initiative to contain the growing cyber-felony. The state government and the state police are developing new cyber felony measures and collecting methods to deal with it with the help of central government and private organizations.

\subsection{STEPS TO PREVENT CYBER FELONY:}

The IT Act of 2000, together with the Penal Code of India, has adequate provisions to deal with prevailing computer felonies. It provides for penalties in the form of imprisonment ranging from two years to life imprisonment and fines / penalties depending on the type of cyber-felony. 
However, the government has taken the following measures to prevent cyber felony:

The cyber felony cells were established in the States and territories of the Union to report and investigate cases of cyber felony.

The government has set up IT research and forensic training laboratories in the states of Kerala, Assam, Mizoram, Nagaland, Arunachal Pradesh, Tripura, Meghalaya, Manipur and Jammu and Kashmir for the training of the police and the judiciary in these states.

Cyber felony investigation programs. National Law School, Bangalore and NALSAR University of Law, Hyderabad, are also involved in conducting various awareness-raising and training programs on law and cyber felony for court officials.

$\square$ Training is provided to police and judicial agents in training laboratories set up by the government.

$\square$ The program for the Universalization of Women Helpline was approved to provide a 24-hour emergency and non-emergency response to all women affected by the violence.

\section{METHODOLOGY:}

\subsection{PRIMARY DATA}

Primary data was not collected for the research paper.

\subsection{SECONDARY DATA}

Secondary data was collected. Therefore, the goal is to better understand the concept, its application and the impact on the economy through other parameters. India ranks third in the world, after the United States and China, as a source of malicious activity in 2014, 9,622 computer felonies were reported, with a $69 \%$ increase compared to 2013. Of the 9,622 computer felony's reported, 7,201 were reported as felonies pursuant to the IT law, 2,272 pursuant to the Criminal Code of India (IPC) and 149 under special and local laws (SLL). 


\section{Computer Felony's for a Decade}

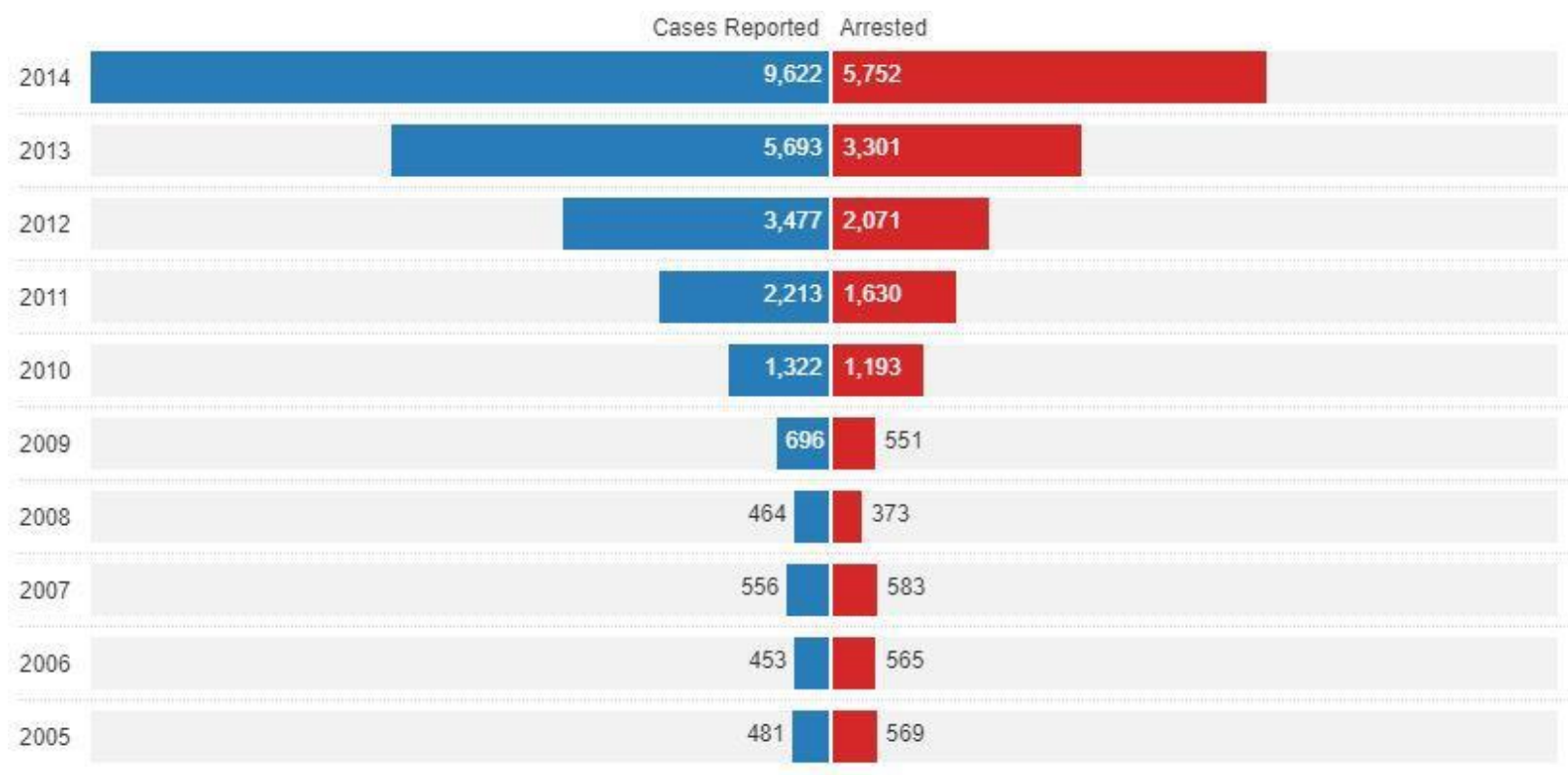

Under the IT law, most - 5,548 cases - have been referred to computer felony's, of which 4,192 in section $66 \mathrm{~A}$, which allows prison sentences of up to two or three years for sending offensive messages through communication service "and related felony's. Section 66A of the computer law was rejected by the Supreme Court in March 2015, stating that "this law has affected the root of freedom and freedom of expression, the two fundamental pillars of democracy". India Spend has previously reported that India has followed Turkey and Russia in restrictive laws on the Internet. India ranked 136, Turkey 149 and Russia 152 in the Press Freedom Index 2015, published by Reporters without Borders, a non-profit organization based in Paris.

\section{CONCLUSION:}

Cyber felony is one of the most crucial problems for countries around the world these days. Any one who has Internet use. Cyber theft is part of the cyber felony, which means robbery performed via computer or the Internet. With the increase in the number of cyber security fraud and felony's, the government is developing refined rules to protect people's interests and protect them from any negative events on the Internet. 


\section{REFERENCES:}

1. http://www.mondaq.com

2. https://telecom.economictimes.indiatimes.com/news

3. https://securitycommunity.tcs.com/infosecsoapbox/articles

4. http://www.helplinelaw.com/employment-criminal-and-labour

5. Anuraj Singh (2007), Volume 05, Issue 06, PP. 11273-11279.

6. http://www.ijser.org 